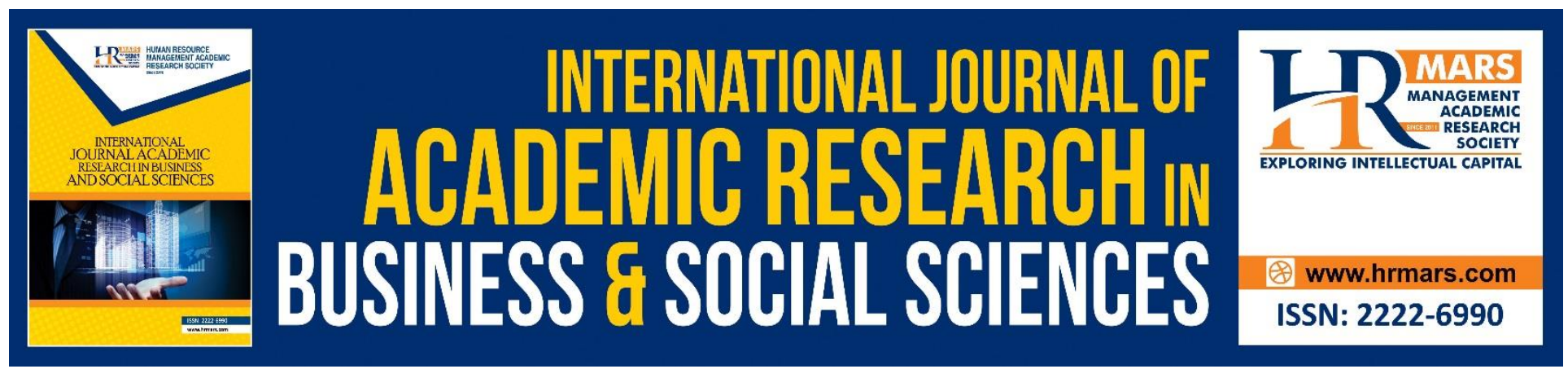

\title{
Effect of Job Characteristics on Job Performance among Employees in the General TV Channels
}

\section{Ammar Hussein}

To Link this Article: http://dx.doi.org/10.6007/IJARBSS/v10-i9/7745

DOI:10.6007/IJARBSS/v10-i9/7745

Received: 15 June 2020, Revised: 17 July 2020, Accepted: 19 August 2020

Published Online: 22 September 2020

In-Text Citation: (Hussein, 2020)

To Cite this Article: Hussein, A. (2020). Effect of Job Characteristics on Job Performance among Employees in the General TV Channels. International Journal of Academic Research in Business and Social Sciences. 10(9), 333344.

Copyright: (C) 2020 The Author(s)

Published by Human Resource Management Academic Research Society (www.hrmars.com)

This article is published under the Creative Commons Attribution (CC BY 4.0) license. Anyone may reproduce, distribute, translate and create derivative works of this article (for both commercial and non-commercial purposes), subject to full attribution to the original publication and authors. The full terms of this license may be seen at: $\underline{\text { http://creativecommons.org/licences/by/4.0/legalcode }}$

Vol. 10, No. 9, 2020, Pg. 333 - 344

Full Terms \& Conditions of access and use can be found at http://hrmars.com/index.php/pages/detail/publication-ethics 


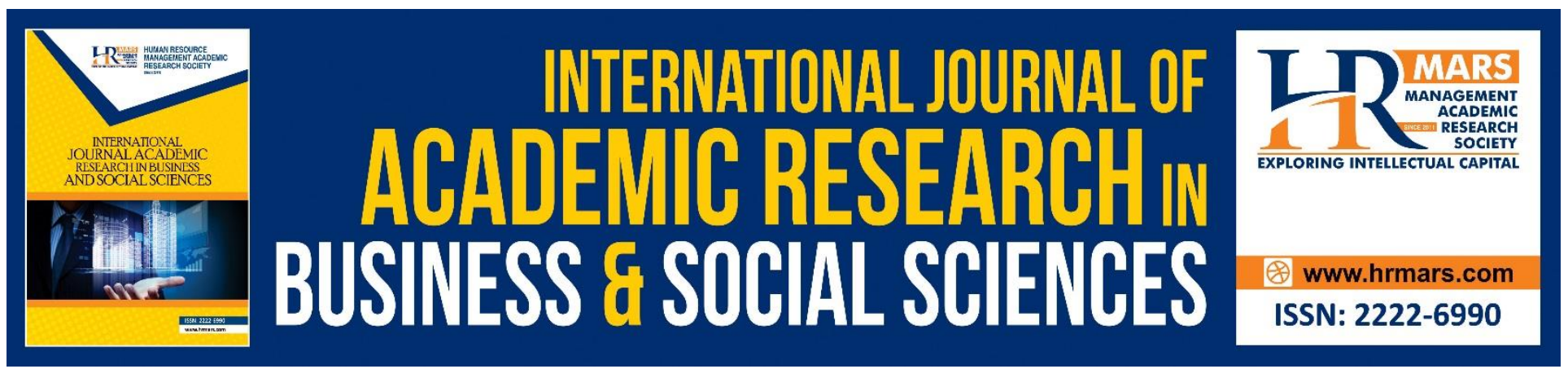

\title{
Effect of Job Characteristics on Job Performance among Employees in the General TV Channels
}

\author{
Ammar Hussein \\ PHD of human resource management from higher institute of business administration Damascus
}

Syria

\begin{abstract}
This study aimed to describe the level of job characteristics and job performance and to examine the relationship between job characteristics and job performance among employees in general TV channels in Syria.

Data were collected from 158 members and the findings indicate that employees of TV channel have assessed that their work is designed with the motivational approach by applying the five dimensions of work which are: skill variety, task identity, task significance, autonomy and feedback.

Also the findings indicated that there is a significant relationship between all job dimension and job performance but with a different levels.
\end{abstract}

Keywords: Job Characteristics, Job Performance.

\section{Introduction}

Much of the history of management and motivation theory is rooted to understand the factors that contribute to increase the levels of job performance and workplace productivity. To do any job an employee should have the ability required and along with ability the willingness of that employee to perform job is also very essential. To create the willingness of employees and to motivate them, managers should design jobs that motivate the employees and satisfy them on work.

Scholars have long recognized that job performance depends heavily on how employees perceive their jobs (e.g., Herzberg, Mausner, \& Snyderman, 1959; Turner \& Lawrence, 1965).

Increasing job performance is among the most theoretically and practically important problems in organizational research (Steers \& Mowday, 1977). Job perceptions scholars have often argued that job performance can be enhanced through the cultivation of perceptions of task characteristics judgments that one's job has a positive impact on other people and on his/her self. (Hackman \& Oldham, 1976)

\section{Problem of the Study}

The problem of this study was based on the fact that there was a lack of knowledge about the relationship between employee's perception of job characteristics and their performance. 
INTERNATIONAL JOURNAL OF ACADEMIC RESEARCH IN BUSINESS AND SOCIAL SCIENCES

Vol. 10, No. 9, 2020, E-ISSN: 2222-6990 @ 2020 HRMARS

\section{Research Objectives}

Based on the problem of the study, the main objectives of this paper were listed as follows:

1. To identify the direct effect of task variety on job performance.

2. To identify the direct effect of task identify on job performance.

3. To identify the direct effect of task significance on job performance.

4. To identify the direct effect of autonomy on job performance.

5. To identify the direct effect of feedback on job performance.

\section{Research Questions}

a) Can an employee's perception of job characteristics predict his or her performance?

b) How the five dimension of variety, identify, significance, autonomy and feedback directly related to job performance for employee?

\section{Importance of Study}

We can brief The importance of this study in two points:

- The importance of this study is based on the trying to find the basic participation of the job characteristics on job performance between employees.

- $\quad$ Based on result we will introduce a proactive solution to reinforcement job performance after evaluated from the employee themselves.

\section{Theoretical Review}

Job performance has become one of the significant indicators in measuring organizational performance in many studies (Wall, et al., 2004).

Additionally, job analysis can also be used in developing performance standard required of each employee (Heneman \& Judge, 2003). Job analysis specifies work behaviors and knowledge, skills, abilities, and other characteristics (KSAOs) required of the job incumbents.

Based on the last points and by realizing the need for designing the jobs of workers, Hackman \& Oldham (1975) presented job characteristics model (JCM).

Most studies on job characteristics adopt the job characteristics model developed by Hackman and Oldham (McCloy et al., 1994).

Even though performance is oftentimes determined by financial figures, it can also be measured through the combination of expected behavior and task-related aspects (Motowidlo, 2003).

Job Characteristics Model influence performance (outcomes) through, motivational processes in the form of critical psychological states. The JCM posits that the way jobs are perceived in terms of the five core job characteristics (Autonomy, task significance, task identity, skill variety and feedback from job) impact three particular psychological reactions to the job. These reactions, referred to as critical psychological states, include; experienced meaningfulness of work (the extent that the work is seen as making a difference to others), felt responsibility (the extent that the worker assumes responsibility for his/her work), and knowledge of results (the extent to which the worker is aware of the quality of his/her work) (Kahya, 2010). 
INTERNATIONAL JOURNAL OF ACADEMIC RESEARCH IN BUSINESS AND SOCIAL SCIENCES Vol. 10, No. 9, 2020, E-ISSN: 2222-6990 @ 2020 HRMARS

\section{Skills Variety and Employee Performance}

Most studies on job characteristics found that skills variety has an important effect on job performance by motivate employee to reinforce their competencies to achieve the increased demands of job (Pincus, 1986). Form other side skill variety introduce the task as a developed process that enriched the mental capabilities of employee by learning from the diversification of skills.

\section{Task identity and Employee Performance}

Task identity is achieved when there is an opportunity to complete a 'whole' piece of work in a job. It involves carrying out several tasks that eventually fit together to make a complete job. This gives the employee a feeling of doing a whole job from beginning to end and realizing a visible output. Consequently the employee attains a sense of achievement and satisfaction in a job (Podsakoff et al., 1990).

Task identity needs to be broadened to role identity jobs. Role identity has implications for employees as it determines 'the role of each individual' when collaborating with others (Tonges, 1998).

\section{Task Significance and Employee Performance}

Social researchers conceptualize task significance as a subjective judgment that is socially constructed in interpersonal interactions, seeking to increase job performance by providing social cues to reframe employees' perceptions of task significance (Griffeth et al., 2000). Although these two theoretical perspectives emphasize different antecedents of task significance, they share the premise that once perceptions of task significance are cultivated, employees are more likely to perform effectively.

\section{Autonomy and Employee Performance}

The autonomy is influenced by role expectations, organizational culture, opportunities for independent decision making and opportunities to influence work life factors such as scheduling(Stewart et al., 2004). Stewart, Stansfield and Tapp (2004) suggests that autonomy as seen by is not about independent practice and decision making but about providing a unique perspective and contribution to care that includes interdisciplinary co-ordination and collaboration

\section{Feedback and Employee Performance}

In order for the employees to perform well organizations must also continuously appraise employees through both formal and informal feedback channels on their performance level and what must be done to enhance their performance (Safari, 2010). Poor performing employees need to receive the most feedback from their supervisor or managers on the measures to take to improve their performance, however, high performing employees also need recognition and feedback about their positive contributions (Wiedower, 2001).

\section{Job Characteristics}

Most studies on job characteristics adopt the job characteristics model developed by Hackman and Oldham (Zalesny \& Ford, 1990). This model incorporates five dimensions of job characteristics, namely task identity, skill variety, task significance, autonomy, and feedback. 


\section{Job Characteristics}

Hackman \& Oldham (1975) empirically tested the relationships among the job characteristics, individual differences in need strength and employee's motivation, satisfaction, performance, and absenteeism on the job. The results indicated that positive relationship was found among job dimensions and dependent measures: motivation, satisfaction, performance and attendance.

Hackman \& Oldham (1975) originally developed the job diagnosis survey (JDS). In this research he described that this theory may not provide the desired results for all the individuals. It is especially suitable for those who have the strong desire for feeling of accomplishment and growth. Individuals who are low on growth need strength may find such job difficult to perform and may feel uncomfortable with it. Hackman \& Oldham (1976) empirically tested the relationships postulated by JCM including the mediating effect of CPS's and moderating effect of GNS. In general all correlations between JC, PS and outcomes (except absenteeism) were positive and negative for absenteeism as expected. The mediating effect of CPS was proved through the partial correlations and multiple regressions. The moderating role of GNS was also proved by determining separate correlations for employees high and low on GNS measurement scale. The correlation results were higher for those who were high on GNS as compared to those who were low on GNS.

Skill Variety is the degree to which a job requires a variety of different activities in carrying out the work, which involve the use of a number of different skills and talents of the employee

Task Identity is the degree to which the job requires the completion of a "whole" and identifiable piece of work (i.e.; doing a job from beginning to end with a visible outcomes).

Task Significance is the degree to which a job has a substantial impact on the lives or work of other people whether in the immediate organization or in the external environment.

Autonomy is the degree to which the job provides substantial freedom, independence, and discretion to the employee in scheduling his or her work and in determining the procedures to be used in carrying it out.

Feedback refers to the degree to which carrying out the work activities required by the job results in the employee obtaining information about the effectiveness of his or her performance.

\section{Job performance}

Even though performance is oftentimes determined by financial figures, it can also be measured through the combination of expected behavior and task-related aspects (Motowidlo, 2003).

Employee performance can be defined as "the process that supports the organizational control system by linking the work of each individual employee or manager to the overall mission of the work unit" (McCloy, Campbell, \& Cudeck, 1994; cf.) so Job performance refers to the effectiveness of individual behaviors that contribute to organizational objectives (Motowidlo, 2003).

\section{Hypotheses}

The proposed study seeks to answer these questions empirically by testing the following hypotheses 
INTERNATIONAL JOURNAL OF ACADEMIC RESEARCH IN BUSINESS AND SOCIAL SCIENCES Vol. 10, No. 9, 2020, E-ISSN: 2222-6990 @ 2020 HRMARS

Hypothesis 1: There is a positive and significant relationship between Skill Variety and job performance.

Hypothesis 2: There is a positive and significant relationship between Task Identity and job performance..

Hypothesis 3: There is a positive and significant relationship between Task Significance and job performance..

Hypothesis 4: There is a positive and significant relationship between Autonomy and job performance.

Hypothesis 5: There is a positive and significant relationship between Feedback and job performance.

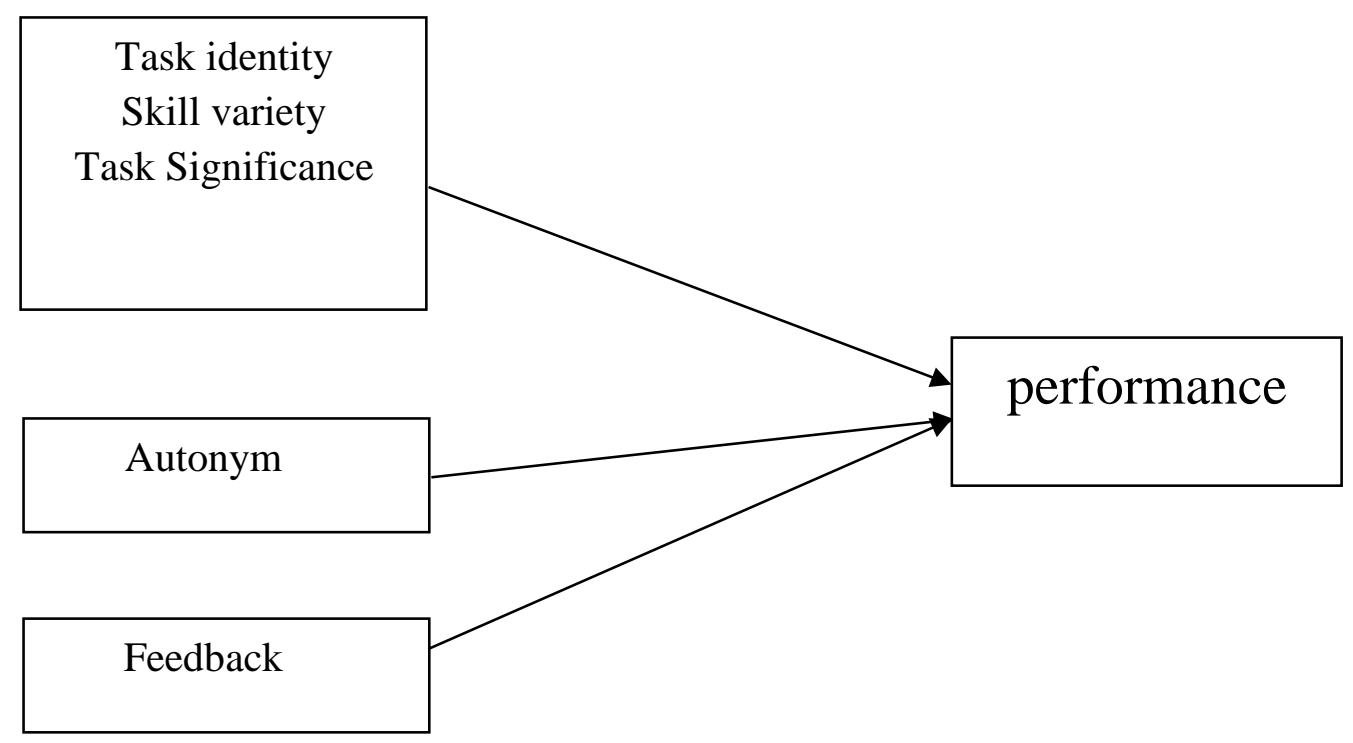

Instruments

Job diagnostic survey (JDS)

Hackamn and Oldham (1976) developed a self-report instrument to measure the five core job features of job characteristics model. The questionnaire consists of 18 items, and items were scored on 5 point Likert type scale.

Job performance Survey

A Questionnaire consisting of 20 Items rated on 5 point Likert type scale is used adapted from JDS to measure job performance. 
INTERNATIONAL JOURNAL OF ACADEMIC RESEARCH IN BUSINESS AND SOCIAL SCIENCES Vol. 10, No. 9, 2020, E-ISSN: 2222-6990 @ 2020 HRMARS

\section{Analysis Technique}

SPSS software was used to analyze the questionnaires a total sample of 163 employees is selected and from this an equal number of questionnaires have been filled up.

\begin{tabular}{|c|c|c|}
\hline Demographics & $\mathbf{N}$ & $\%$ \\
\hline Gender & & \\
Male & 78 & 47 \\
Female & 85 & 53 \\
\hline Age & & \\
25 and below & 45 & 28 \\
$21-30$ & 48 & 29 \\
$31-40$ & 50 & 30 \\
Above 40 & 20 & 13 \\
\hline Education & & \\
High school & 36 & 22 \\
Institute & 67 & 41 \\
University & 60 & 37 \\
\hline
\end{tabular}

Table 1. Mean standard deviation and the level of job characteristics as perceived by employees.

\begin{tabular}{|l|c|c|c|}
\hline $\begin{array}{l}\text { Dimension of job } \\
\text { characteristics }\end{array}$ & Mean & SD & Assessment \\
\hline Skill variety & 5.2 & 1.33 & High \\
\hline Task identity & 5.3 & 1.12 & High \\
\hline Task significance & 4.3 & 1.25 & Moderate \\
\hline Autonomy & 4.56 & 1.33 & Moderate \\
\hline $\begin{array}{l}\text { Feedback from job } \\
\text { itself }\end{array}$ & 5.01 & 1.89 & Moderate \\
\hline $\begin{array}{l}\text { Feedback from } \\
\text { agents }\end{array}$ & 4.69 & 1.44 & High \\
\hline Dealing with others & 4.79 & 1.36 & 1.78 \\
\hline $\begin{array}{l}\text { Overall job } \\
\text { characteristics }\end{array}$ & 5.23 & & Is \\
\hline
\end{tabular}

That means jobs are designed with a variety of high skill. Task identity is clear and with clear task significance that provides a clear feedback of their work either to received praise or reprimand, or to give awards for outstanding workers or to give penalties for employees who make mistakes. 
INTERNATIONAL JOURNAL OF ACADEMIC RESEARCH IN BUSINESS AND SOCIAL SCIENCES Vol. 10, No. 9, 2020, E-ISSN: 2222-6990 @ 2020 HRMARS

Table 2: alpha, standard deviations, and correlations

\begin{tabular}{|c|c|c|c|c|c|c|}
\hline & $\begin{array}{c}\text { Skill } \\
\text { variet } \\
y\end{array}$ & $\begin{array}{c}\text { Task } \\
\text { significanc } \\
\mathrm{e} \\
\end{array}$ & $\begin{array}{c}\text { Task } \\
\text { identit } \\
y\end{array}$ & $\begin{array}{c}\text { Autonom } \\
y\end{array}$ & $\begin{array}{c}\text { Feedbac } \\
k\end{array}$ & $\begin{array}{c}\text { Job } \\
\text { performan } \\
\text { ce }\end{array}$ \\
\hline Skill variety & $(88)$ & & & & & \\
\hline $\begin{array}{c}\text { Task } \\
\text { significanc } \\
\text { e }\end{array}$ & $.23 * *$ & (82) & & & & \\
\hline $\begin{array}{c}\text { Task } \\
\text { identity }\end{array}$ & $.24 *$ & $.23 * *$ & (75) & & & \\
\hline Autonomy & $.25 * *$ & $.22 * *$ & $.18^{* *}$ & (78) & & \\
\hline Feedback & $.32 * *$ & $.17^{*}$ & $.33^{*}$ & $.28 * *$ & $(77)$ & \\
\hline $\begin{array}{c}\text { Job } \\
\text { performan } \\
\text { ce }\end{array}$ & $.33^{* *}$ & $.25 * *$ & $.32 * *$ & $.26 * *$ & $.20 * *$ & (75) \\
\hline
\end{tabular}

Note. $* p<05, * * p<01$

\section{Results and Discussion}

Based on the table 2 there is a positive and significant relationship between skill variety and job performance.

Job characteristics have positive and significant effects on job performance as stated with the previous studies (Bhuidan and Menguc, 2002). That means jobs are designed with a variety of high skill can increase the level of performance. (Dodd, \& Ganster, 1996)

Based on the table 2 there is a positive and significant relationship between Task significance and job performance.

Researchers studying both job design and social information processing (Salancik \& Pfeffer, 1978) have proposed that when employees perceive their jobs as high in task significance, they display higher job performance.

Based on the table 2 there is a positive and significant relationship between Task identity and job performance.

Tonges (1998) asserts that role ambiguity is related to lack of clarity of job scope, responsibility and function of each team member, vague task definition, and inconsistent direction from supervisors.

Planning, coordinating and communicating are required to minimize role tension as well as clarifying accountability. Furthermore, role conflict is associated with violation of principles accountability and unity of command

Goal setting may be a strategy to integrate activities and to understand their relationship to the whole, also has the potential to enhance role clarity and minimize role ambiguity through clarification of the goals of a job which consequently enhance understanding of the relationship between their role and the role of others (Umstot, et al., 1978) 
INTERNATIONAL JOURNAL OF ACADEMIC RESEARCH IN BUSINESS AND SOCIAL SCIENCES Vol. 10, No. 9, 2020, E-ISSN: 2222-6990 @ 2020 HRMARS

Based on the table 2 there is a positive and significant relationship between autonomy and job performance.

Lincoln, (2010) argues that when a specific job is designed to provide the individual with autonomy in planning and conducting the job, his or her sense of responsibility for work-related outcomes is enhanced. At a general level job, therefore, autonomy (or freedom in the job) is an important mechanism impacting employees' motivation and thus their performance. (Stewart et al. 2004)

Autonomy creates an opportunity to experience responsibility for patient outcomes and thus a feeling of significance and identity. However, studies have indicated that not all desire autonomy in their jobs. Those with relatively low preference for autonomy have been found to have higher absenteeism (Lansbury, R., 1988).

Based on the table 2 there is a positive and significant relationship between Feedback and job performance.

Hackman and Oldham (1980) define autonomy as having substantial conclusion trol over aspects of one's work. It is the individual's control of his or her work. As much as possible, employees should have inputs on how their jobs are done, the order of tasks, the speed of work, among others and opportunities to participate in decisions which affect them. (Inge Houkes,Peter P. M. Janssen, Jan de Jonge , Arnold B. Bakker, 2003)

\section{Limitations and Future Research}

- There are several limitations of this study that can be addressed in future research.

- First, the demographics of this study limit the external reliability of the findings specifically due to the uniqueness of the media sector in Syria.

- Second, employee in the media sector may have different working conditions than other employee in other sectors.

- Third, job performance must necessarily be studied using self-reports, non-self-report measures of objective and subjective assessment that would have enhanced the validity of the findings.

- Finally, never mind for the later studies to test the relationships with many factors such as organizational, personal, occupational and cultural elements apart from job characteristics, demographic variable and role ambiguity that may influence job performance and should be explored for further research.

\section{Conclusion}

To sum up, job characteristics analysis is done to determine where we need to do enrichment as a proactive method that aim to treat any lack of performance after diagnosis which dimension is low and need to reinforce

After that if the performance appraisal still under the wanted range we should search and evaluate another variables like tools, training, benefits ... etc. 
INTERNATIONAL JOURNAL OF ACADEMIC RESEARCH IN BUSINESS AND SOCIAL SCIENCES

Vol. 10, No. 9, 2020, E-ISSN: 2222-6990 @ 2020 HRMARS

\section{References}

Abdullah, N. N. (2004). Job satisfaction in relation to work motivation among sales representatives. Unpublished master's dissertation, Quaid-e-Azam University, Islamabad.

Amabile, T. M., Hill, K. G., Hennessey, B. A., \& Tighe, E. M. (1994). The Work Preference Inventory: Assessing intrinsic and extrinsic motivational orientations. Journal of Personality and Social Psychology, 66, 950- 967.

Bhuain, S. N., Al-Shammari, E. S., \& Jefri, O. A. (2001). Work-related attitudes and job characteristics of expatriates in Saudi Arabia. Thunderbird International Business Review, 43(1), 21-31.

Bodewes, W. E. (2002). Formalization and innovation revisited. European Journal of Innovation Management, 5(4), 214-223.

Boonzaaier, B., Ficker, F., Rust, B. (2001). A review of research on the job characteristics model and the attendant job diagnostic survey, South Africa. J. Bus. Manage. 32(1), 11-29

Buys, M. A., Olckers, C., \& Schaap, P. (2007). The construct validity of the revised job diagnostic survey. South African Journal of Business Management, 38, 33-40.

Champoux, J. E. (1991). A multivariate test on the job characteristics theory of work motivation. Journal of Organizational Behavior, 12(5), 431-446.

Chang, C. S., \& Lee, M. S. (2006). Relationships among personality traits, job characteristics, and organizational commitment: An empirical study in Taiwan. The Business Review, Cambridge, 6(1), 201-207.

Cherrington, D. J., \& England, J. L. (1980). The desire for an enriched job as a moderator of the enrichment-satisfaction relationship. Organizational Behavior and Human Performance, 25, 139-159

Dodd, N. G., \& Ganster, D. C. (1996). The interactive effects of task variety, autonomy, and feedback on attitudes and performance. Journal of Organizational Behavior, 17, 329-347.

Droar, D. (2006). The Job characteristics model. Retrieved May 1, 2009, from http:// www.arrod.co.uk/archive/concept_job_characteristics.php.

Fried, Y., \& Ferris, G. R. (1987). The validity of the job characteristics model: a review and metaanalysis. Personnel Psychology, 40, $287-322$.

Griffeth, R. W., Horn, P. W., \& Gaertner, S. (2000). A meta-analysis of antecedents and correlates of employee turnover: Update, moderator tests, and research implications for the next millennium. Journal of Management, 26(3), 463-488.

Hackman, J. R., Oldham, G. R. (1976). Motivation through the design of work: Test of a theory. Organizational behavior \&human performance, 16, 250-279.

Hackman, J. R. (1974). Work redesign. In J. R. Hackman \& J. L. Shuttle (Eds.). Improving life at work (pp. 96-162). Santa Monica, CA: Goodyear.

Hackman, J. R., \& Oldham, G. (1975). Development of the job diagnostic survey. Journal of Applied Psychology, 60, 159-170.

Hackman, J. R., \& Oldham, G. R. (1976). Motivation through the design of work: Test of a theory. Organizational Behavior and Human Performance, 16, 250-279.

Hackman, J. R., \& Oldham, G. R. (1980). Work Redesign. Mass: Addison-Wesley.

Heneman, H. G., \& Judge, T. A. (2003). Staffing organizations (4th ed.) Middleton, MI: McGraw Hill.

Herzberg, F. (1968). One more time: How do you motivate employees? Harvard Business Review, 5362 
INTERNATIONAL JOURNAL OF ACADEMIC RESEARCH IN BUSINESS AND SOCIAL SCIENCES

Vol. 10, No. 9, 2020, E-ISSN: 2222-6990 @ 2020 HRMARS

Hogan, E.A. 62 Martell, D.A. (1987). A confirmatory structural equation analysis of the job characteristics model. Organizational Behavior and human Decision Processes, 39: 242263Sdaszak, JR, \&

Humphrey, S. E., Nahrgang, J. D., \& Morgeson, F. P. (2007). Integrating motivational, social, and contextual work design features: A meta-analytic summary and theoretical extension of the work design literature. Journal of Applied Psychology, 92(5), 1332-1356.

Judge, T. A., Heller, D., \& Mount, M. K. (2002). "Five-Factor Model of Personality and Job Satisfaction: a Meta-Analysis," Journal of Applied Psychology, 87(3), 530-541.

Kahya, M. (2010). The effects of job performance on effectiveness, International Journal of Industrial Ergonomics, 39(1), 96-104.

Lansbury, R. (1988). Performance Management: A Process Approach, Human Resource Management, Australia, 46-55.

Lawler, E. E., \& Hall, D. T. (1970). Relationship of job characteristics to job involvement, satisfaction, and intrinsic motivation. Journal of Applied Psychology, 54(4), 305-312.

Mansoor Nisar Mughal. (2016). Impact of Job Characteristics on Turnover Intentions: A study of the Front Line Employees in Commercial Banks, Academy of Contemporary Research Journalm Volume IV, Issue I, 2015, 32-45

McCloy, R. A., Campbell, J. P., \& Cudeck, R. (1994). A confirmatory test of a model of performance determinants. Journal of Applied Psychology, 79, 493-505.

Motowidlo, S. J. (2003). Job performance. In W. C. Borman, D. R. Ilgen, \& R. J. Klimoski (Eds.), Handbook of psychology: Vol.12. Industrial and organizational psychology (pp. 39-53). Hoboken, NJ: John Wiley \& Sons.

Noraani Mustapha, Aminah Ahmad, 2010, Job Characteristics as Antecedents of Intention to Stay and Mediating Effects of Work Family Facilitation and Family Satisfaction among Single Mothers in Malaysia, Vol. 1 No. 3;

Pincus, J. D. (1986). Communication satisfaction, job satisfaction, and job performance. Human Communication Research, 12(3), 395-419.

Podsakoff, P. M., MacKenzie, S. B., Moorman, R. H., \& Fetter, R. (1990). Transformational leader behaviors and their effects on followers' trust in leader, satisfaction, and organizational citizenship behaviors. Leadership Quarterly, 1, 107-142.

Saavedra, \& Kwun, S. K. (2000). Affective states in job characteristics theory. Journal of Organizational Behavior, 21, 131-146.

Safari, D.A, (2010). Factors Influencing the Effectiveness of the Employee Appraisal System at KEMRI, Nairobi. Moi University School of Business,

Salancik, G. R., \& Pfeffer, J. (1978). A social information processing approach to job attitudes and task design. Administrative Science Quarterly, 23, 224-253.

Slocum, J. W. (1981). Job redesign: Improving the quality of work life. Journal of Experiential Learning and Simulation, 17-36.

Smits, S. J., Tanner, J. R., \& McLean, E. R. (1993). Job Characteristic preference reality discrepancies and the job career attitudes of I/S professionals. Association for Computing Machinery, 120130.

Song, J. H., Martens, J., McCharen, B., \& Ausburn, L. J. (2010). The complex structure of teacher turnover intention: Multi-structural relationships among organizational culture, job autonomy, and turnover intention in CTE Teachers. Oklahoma: Oklahoma State University. 
INTERNATIONAL JOURNAL OF ACADEMIC RESEARCH IN BUSINESS AND SOCIAL SCIENCES

Vol. 10, No. 9, 2020, E-ISSN: 2222-6990 @ 2020 HRMARS

Spector, P. E., \& Jex, S. M. (1991). Relations of job characteristics from multiple data sources with employee affect, absence, turnover intentions, and health. Journal of Applied Psychology, 76, 46-53.

Steers, R. M., \& Mowday, R. T. (1977). The motivational properties of tasks. Academy of Management Review, 2, 645-658.

Stewart, J., Stansfield, K., \& Tapp, D.M. (2004). Clinical nurses' understanding of autonomy: Accomplishing patient goals through interdependent practice. Journal of Nursing Administration, 34(10), 443-450.

Tonges, M. C. (1998). Job design for nurse case managers: Intended and unintended effects on satisfaction and well-being. Nursing Case Management, 3(1), 11-23.

Umstot, D. D., Mitchell, T. R., \& Bell, C. H. (1978). Goal setting and job enrichment: An integrated approach to job design. Academy of Management Review, October, 867-879.

Wall, T. D., Michie, J., Patterson, M., Wood, S. J., Sheehan, M., Clegg, C. W., \& West, M. (2004). On the validity of subjective measures of company performance. Personnel Psychology, 57, 95118.

Wiedower, K. A. (2001). A shared vision: The relationship of management communication and contingent reinforcement of the corporate vision with job performance, organizational commitment, and intent to leave. Unpublished doctoral dissertation, Alliant International University, California.

Zalesny, M. D., \& Ford, J. K. (1990). Extending the social information processing perspective: New links to attitudes, behaviors, and perceptions. Organizational Behavior and Human Decision Processes, 47, 205-246. 